University of Montana

ScholarWorks at University of Montana

10-2006

\title{
Frequent Fire Alters Nitrogen Transformations in Ponderosa Pine Stands of the Inland Northwest
}

Thomas H. Gremer

Anna Sala

University of Montana - Missoula, sala@mso.umt.edu

Follow this and additional works at: https://scholarworks.umt.edu/biosci_pubs

Part of the Biology Commons

Let us know how access to this document benefits you.

\section{Recommended Citation}

Gremer, Thomas H. and Sala, Anna, "Frequent Fire Alters Nitrogen Transformations in Ponderosa Pine Stands of the Inland Northwest" (2006). Biological Sciences Faculty Publications. 16.

https://scholarworks.umt.edu/biosci_pubs/16

This Article is brought to you for free and open access by the Biological Sciences at ScholarWorks at University of Montana. It has been accepted for inclusion in Biological Sciences Faculty Publications by an authorized administrator of ScholarWorks at University of Montana. For more information, please contact

scholarworks@mso.umt.edu. 


\title{
FREQUENT FIRE ALTERS NITROGEN TRANSFORMATIONS IN PONDEROSA PINE STANDS OF THE INLAND NORTHWEST
}

\author{
Thomas H. DeLuca ${ }^{1,3}$ and Anna Sala ${ }^{2}$ \\ ${ }^{1}$ Department of Ecosystem and Conservation Sciences, University of Montana, Missoula, Montana 59812 USA \\ ${ }^{2}$ Division of Biological Sciences, University of Montana, Missoula, Montana 59812 USA
}

\begin{abstract}
Recurrent, low-severity fire in ponderosa pine (Pinus ponderosa)/interior Douglas-fir (Pseudotsuga menziesii var. glauca) forests is thought to have directly influenced nitrogen $(\mathrm{N})$ cycling and availability. However, no studies to date have investigated the influence of natural fire intervals on soil processes in undisturbed forests, thereby limiting our ability to understand ecological processes and successional dynamics in this important ecosystem of the Rocky Mountain West. Here, we tested the standing hypothesis that recurrent fire in ponderosa pine/Douglas-fir forests of the Inland Northwest decreases total soil $\mathrm{N}$, but increases $\mathrm{N}$ turnover and nutrient availability. We compared soils in stands unburned over the past 69-130 years vs. stands exposed to two or more fires over the last 130 years at seven distinct locations in two wilderness areas. Mineral soil samples were collected from each of the seven sites in June and July of 2003 and analyzed for $\mathrm{pH}$, total $\mathrm{C}$ and $\mathrm{N}$, potentially mineralizable $\mathrm{N}(\mathrm{PMN})$, and extractable $\mathrm{NH}_{4}^{+}, \mathrm{NO}_{3}^{-}, \mathrm{PO}_{4}{ }^{-3}, \mathrm{Ca}^{+2}, \mathrm{Mg}^{+2}$, and $\mathrm{K}^{+}$. Nitrogen transformations were assessed at five sites by installing ionic resin capsules in the mineral soil in August of 2003 and by conducting laboratory assays of nitrification potential and net nitrification in aerobic incubations. Total $\mathrm{N}$ and PMN decreased in stands subjected to multiple fires. This loss of total $\mathrm{N}$ and labile $\mathrm{N}$ was not reflected in concentrations of extractable $\mathrm{NH}_{4}{ }^{+}$and $\mathrm{NO}_{3}{ }^{-}$. Rather, multiple fires caused an increase in $\mathrm{NO}_{3}{ }^{-}$sorbed on ionic resins, nitrification potential, and net nitrification in spite of the burned stands not having been exposed to fire for at least 12-17 years. Charcoal collected from a recent fire site and added to unburned soils increased nitrification potential, suggesting that the decrease of charcoal in the absence of fire may play an important role in $\mathrm{N}$ transformations in firedependent ecosystems in the long term. Interestingly, we found no consistent effect of fire frequency on extractable $\mathrm{P}$ or alkaline metal concentrations. Our results corroborate the largely untested hypothesis that frequent fire in ponderosa pine forests increases inorganic $\mathrm{N}$ availability in the long term and emphasize the need to study natural, unmanaged sites in far greater detail.
\end{abstract}

Key words: charcoal; Douglas-fir; fire frequency; Inland Northwest USA; nitrification; nitrogen mineralization; Pinus ponderosa; ponderosa pine; Pseudotsuga menziesii; wilderness.

\section{INTRODUCTION}

Fire is a natural disturbance in many ecosystems of the world that has profound effects on ecosystem dynamics and function. Prior to European settlement, many pure and mixed ponderosa pine forests of the western United States were subjected to frequent, lowseverity fires (Gruell 1983, Veblen and Lorenz 1986, Covington and Moore 1994a, Arno et al. 1995, Swetnam and Baisan 1996, Allen et al. 1998, Brown et al. 1999, Mast et al. 1999, Moore et al. 1999, Kaufmann et al. 2000, Schoennagel et al. 2004) that maintained open, uneven-aged stands, often dominated by grassy understories (Covington and Moore 1994a, Covington et al. 1997, Fulé et al. 1997). Western ponderosa pine forests are considered to be $\mathrm{N}$ limited due to the

Manuscript received 3 November 2005; revised 1 March 2006; accepted 14 March 2006. Corresponding Editor: J. P. Schimel.

${ }^{3}$ E-mail: tom.deluca@cfc.umt.edu accumulation of organic matter composed of low-N woody residues (Wagle and Kitchen 1972, Mandzak and Moore 1994). The active exclusion of fire implemented in these ecosystems over the last century has changed forest structure and function including increases in stand density (e.g., MacKenzie et al. 2004) and changes in understory composition (Covington and Moore 1994b, Keane et al. 2002, MacKenzie et al. 2004). Such changes were predicted to further slow down $\mathrm{N}$ turnover rates and reduce inorganic $\mathrm{N}$ availability and forest productivity due to the accumulation of low-quality pine litter that decomposes more slowly than grass or open-canopy litter (Hunt et al. 1988, Covington and Sackett 1992, Covington and Moore 1994b, Hart et al. 2005). Consistent with this, MacKenzie et al. $(2004,2005)$ showed a decrease in litter quality and $\mathrm{N}$ turnover rates with time since fire in ponderosa pine forests of the interior Northwest. Studies of the short-term effects of prescribed and wildfire in fire-excluded ponderosa pine ecosystems on 
TABLE 1. Site characteristics for seven sites with stands of different fire frequency in the Selway Bitterroot (SB) and Frank Church (FC) wilderness areas of western Montana and northern Idaho, USA.

\begin{tabular}{|c|c|c|c|c|c|c|c|c|}
\hline \multirow[b]{2}{*}{ Site $\dagger$} & \multirow{2}{*}{$\begin{array}{l}\text { No. fires } \\
\text { per stand }\end{array}$} & \multirow{2}{*}{$\begin{array}{c}\text { Mean aspect } \\
\left({ }^{\circ}\right)\end{array}$} & \multirow{2}{*}{$\begin{array}{l}\text { Mean elevation } \\
(\mathrm{m})\end{array}$} & \multirow{2}{*}{$\begin{array}{c}\text { Mean slope } \\
\left({ }^{\circ}\right)\end{array}$} & \multicolumn{4}{|c|}{ Year of burn } \\
\hline & & & & & First burn & Second burn & Third burn & Fourth burn \\
\hline \multirow{2}{*}{$23 \mathrm{M}$} & 0 & 88.7 & 805 & 32.7 & 1910 & 1934 & & \\
\hline & 3 & 134.7 & 870 & 33.3 & 1910 & 1934 & 1992 & \\
\hline \multirow{2}{*}{ MB } & 0 & 108.7 & 1177 & 18.7 & 1919 & & & \\
\hline & 3 & 250.7 & 1536 & 32.7 & 1919 & 1960 & 1987 & \\
\hline \multirow{2}{*}{ WWR } & 0 & 220.0 & 1285 & 30.0 & 1870 & & & \\
\hline & 3 & 93.3 & 949 & 35.0 & 1919 & 1933 & 1988 & \\
\hline \multirow{2}{*}{$\mathrm{LC}$} & 0 & 304.7 & 1552 & 21.0 & 1870 & & & \\
\hline & 2 & 273.3 & 1577 & 35.0 & 1924 & 1988 & & \\
\hline \multirow[t]{2}{*}{ BR } & 0 & 61.3 & 1665 & 37.3 & 1870 & & & \\
\hline & 3 & 49.3 & 1464 & 29.3 & 1914 & 1944 & 1992 & \\
\hline \multirow[t]{2}{*}{$\mathrm{DC}$} & 0 & 166.0 & 860 & 17.3 & 1870 & & & \\
\hline & 2 & 202.7 & 936 & 23.3 & 1919 & 1979 & & \\
\hline \multirow[t]{2}{*}{$\mathrm{MC}$} & 0 & 270.0 & 957 & 33.3 & 1870 & & & \\
\hline & 4 & 258.0 & 915 & 42.3 & 1910 & 1934 & 1981 & 1987 \\
\hline
\end{tabular}

$\dagger$ Site codes: 23M, Twenty Three Mile (SB); MB, MacKay Bar (FC); WWR, White Water Ranch (FC); LC, Lake Como (SB); BR, Bullion Ridge (FC); DC, Ditch Creek (FC); MC, Moose Creek (SB).

\$ At $23 \mathrm{M}$ what we had initially identified as an unburned site (unburned since 1910) had in fact burned in 1910 and 1934 , and the three-burn site burned one additional time, in 1992.

the $\mathrm{N}$ status and dynamics show a temporary increase in inorganic $\mathrm{N}$ after fire (Monleon et al. 1997, Kaye and Hart 1998, DeLuca and Zouhar 2000, Chormanska and DeLuca 2001, Gundale et al. 2005, Smithwick et al. 2005). However, such an effect is short lived, and after several years, levels of inorganic $\mathrm{N}$ in burned soils fall close to or even below those in unburned controls (DeLuca and Zouhar 2000, Gundale et al. 2005). Moreover, total $\mathrm{N}$ has been found to decrease following restoration treatments (including fire) or following repeated prescribed fire events (Wright and Hart 1997, Kaye and Hart 1998, DeLuca and Zouhar 2000).

The extent to which natural, recurrent low-severity fire in dry or mixed ponderosa pine ecosystems maintains lower total $\mathrm{N}$ stocks, higher $\mathrm{N}$ transformation rates, and increased inorganic $\mathrm{N}$ availability requires studies on the long-term effects of natural, repeated fire in natural, undisturbed stands subjected to frequent fires, and a comparison with similar stands that have remained unburned during the period of active fire exclusion. To our knowledge, no such comparisons are available to date, which may reflect the challenge to establish such natural reference stands. While studies on changes in forest structure and soil properties with increasing time since fire in ponderosa pine systems (MacKenzie et al. 2004) are useful to understand successional processes, they provide no information on the effects of recurrent, low-severity fires on these properties. Similarly, conclusions derived from changes in soil properties and $\mathrm{N}$ cycling after wildfire or the application of first entry or repeated prescribed fire in fire-excluded stands (e.g., Monleon et al. 1997, Wright and Hart 1997, Feeney et al. 1998, Stone et al. 1999, DeLuca and Zouhar 2000, Prieto-Fernandez et al. 2000, Chormanska and DeLuca 2001, Gundale et al. 2005, Hart et al. 2005) may be misleading because of "memory effects" in fire-excluded stands (e.g., accumulation of ladder and surface fuels and organic matter combined with potential changes in litter quality and microbial dynamics) that may not be easily reversed after the application of single or repeated prescribed fire. Knowledge of the effects of frequent natural fire on $\mathrm{N}$ cycling in ponderosa pine ecosystems and the changes that occur in the absence of fire is crucial for understanding the mechanisms of successional dynamics after natural disturbances and for the implementation of management practices intended to reverse the effects of fire exclusion in these systems and restore them to presettlement structure and function (see Allen et al. 2002).

The purpose of the work reported here was to determine how natural, repeated fires over a 69-130 year period influence nutrient availability and $\mathrm{N}$ transformations. Specifically, we assessed total $\mathrm{N}$ capital, $\mathrm{N}$ turnover, and availability of inorganic $\mathrm{N}$, alkaline metal, and $\mathrm{P}$ in natural, unlogged stands of ponderosa pine/ Douglas-fir forests of the Inland Northwest, and we tested the standing hypothesis that recurrent fire decreases total soil $\mathrm{N}$, but increases $\mathrm{N}$ turnover and nutrient availability. Studies were conducted within or adjacent to two wilderness areas in western Montana and northern Idaho in the interior northern Rocky Mountains. Each site had a stand that had not experienced fire in the past $69-130$ years, and a stand that had experienced two or more fires during the past 130 years. Therefore we were able to compare $\mathrm{N}$ dynamics in frequently burned stands with stands not affected by fire during the fire exclusion period.

\section{Materials And Methods}

\section{Site description}

A total of seven sites (Table 1) were selected nearby (within $10 \mathrm{~km}$ of the boundary ) or within wilderness 
TABLE 2. Depth of $\mathrm{O}$ soil horizon and selected physical and chemical properties of mineral soils at seven wilderness sites in western Montana and northern Idaho, USA.

\begin{tabular}{lcccccr}
\hline \hline & & & \multicolumn{3}{c}{ Soil components $(\mathrm{g} / \mathrm{kg})$} \\
\cline { 4 - 6 } Site $\dagger$ & O horizon $(\mathrm{cm})$ & $\mathrm{pH}$ & Total C & Total N & Sand & Clay \\
\hline 23M & 3.5 & 4.6 & 21.2 & 0.8 & 760 & 100 \\
WWR & 3.5 & 5.0 & 14.1 & 0.6 & 720 & 90 \\
MB & 2.6 & 5.0 & 23.0 & 1.1 & 750 & 80 \\
CL & 3.3 & 4.9 & 34.7 & 1.0 & 700 & 100 \\
BR & 3.3 & 4.5 & 23.8 & 0.9 & 810 & 60 \\
DC & 2.0 & 4.9 & 21.4 & 0.8 & 800 & 70 \\
MC & 3.7 & 4.6 & 23.3 & 0.9 & 770 & 80 \\
\hline
\end{tabular}

$\dagger$ See Table 1 for site codes.

areas of western Montana and northern Idaho (Selway Bitterroot and Frank Church River of No Return wilderness, an area of $>14828 \mathrm{~km}^{2}$; see Plate 1) following an exhaustive analysis of GIS layers of fire history, potential vegetation, and topography. The criteria for site selection included sites with Douglas-fir and ponderosa pine as potential vegetation, slope $<30 \%$, and within $8 \mathrm{~km}$ of the Wilderness boundary. Based on these criteria, further preliminary selection of sites was made to comprise two forest stands subjected to different fire events within the same watershed or small geographic unit: (a) sites unburned at least since 1910, and (b) sites burned two or more times with at least one fire between 1910 and 1940 and another between 1940 and 2000 (see Plate 1). Note that the lack of fire in unburned stands may originate from both natural variability and active fire exclusion.

During initial field reconnaissance in 2003, we identified different fire-frequency stands within each selected site based on existing U.S. Fire Service fire history maps, GPS coordinates, and visual reconnaissance based on presence of charcoal and fire-scarred trees. Fire-scarred trees were cored (Barrett et al. 1991) and analyzed further in the laboratory. From this initial field reconnaissance a total of seven sites were selected. While approximate, our reconnaissance was generally sufficient to distinguish boundaries between different fires, where abrupt changes in vegetation and fire-related signs, not related to changes in slope and exposure, occurred. In most cases, fire boundaries approximately matched those in the fire maps, except at Twenty Three Mile (23M, Table 1), where there were some discrepancies. Detailed a posteriori fire history analyses were conducted during the summer of 2005 at $23 \mathrm{M}$ as well as at MacKay Bar (E. Heyerdahl, unpublished data).

Results showed that at $23 \mathrm{M}$ what we had initially identified as an unburned site (unburned since 1910) had in fact burned in 1910 and 1934, and the three-burn site burned one additional time, in 1992. At MB, the fire history matched our reconnaissance. While it was not possible to match our ideal design with three fire frequency stands on each site, each site contained two stands, one stand unburned for the past 69-130 years and one burned at least twice during the 20th century
(Table 1). For simplicity, we refer to the first as "unburned" and to the second as "frequently burned." Except for 23M, where the frequently burned stand had only one additional fire relative to the unburned stand, all other frequently burned stands had at least two additional fires relative to the unburned stands. Note that while many dry ponderosa pine systems were historically subject to a short fire return interval, the fire return interval in our frequently burned stands is within the same range as in mixed ponderosa pine systems of the northern Rocky Mountains, where there is more variability in time and space (Schoennagel et al. 2004), and fire return intervals of 25 years or more are not uncommon (Arno and Allison-Bunnell 2002).

All stands at all sites have a uniform living-tree component $>150$ years, indicating that they had not experienced a stand-replacing fire during the 20th century. All sites are dominated by ponderosa pine and Douglas-fir with limited presence of grand fir (Abies grandis) and Rocky Mountain maple (Acer glabrum). The understory was composed of a mixture of shrubs, forbs, and grasses typical of these mixed forests (see MacKenzie et al. 2004; E. Keeling, A. Sala, and T. H. DeLuca, unpublished manuscript). Although some Nfixing herbs (e.g., Lupinus spp.) and shrubs (Ceanothus spp.) are present in these sites, there was no consistent trend in the presence of $\mathrm{N}$-fixing species and occurrence of fire (E. Keeling, A. Sala, and T. H. DeLuca, unpublished manuscript). Vegetation analyses indicate that while the absence of fire increases the density of shade-tolerant trees (Douglas-fir and grand fir), the composition of the understory is more sensitive to site effects than to fire history (E. Keeling, A. Sala, and T. H. DeLuca, unpublished manuscript). Soils at all sites were shallow, skeletal Dystrocryepts. Basic physical and chemical properties of the soils at the seven sites are presented in Table 2.

The remote nature of these sites combined with restrictions set upon instrumentation of sites in federally designated Wilderness Areas imposed some limitations. Therefore, most of the analyses conducted in this study, with the exception of the resin-sorbed inorganic N, involved the collection and return of soil samples to the laboratory environment. Laboratory indices of $\mathrm{N}$ turn- 
over may not reflect real-time, in-situ dynamics of these biotic processes, but by using a suite of methodologies we attempted to overcome the specific limitations of each individual method (Schimel and Bennett 2004).

\section{Sample collection and analysis}

For each stand at each site, the longest distance along the main slope was determined from topographic maps and in the field. Three stratified points along this line were selected such that they approximately divided the line in four sections. A $400-\mathrm{m}^{2}$ plot $(20 \times 20 \mathrm{~m})$ was laid out at each stratified point (three plots per stand), with the plot center located at a random distance from the stratified point and perpendicular to the longest distance line.

Composite soil samples (eight per subplot) were collected from all seven sites in the summer of 2003. Both forest floor (surface organic horizons) and mineral soil samples were collected. Forest floor samples were collected by placing a $20 \mathrm{~cm}$ diameter cylinder on the ground, working it into the forest floor in the center of a $1 \times 1 \mathrm{~m}$ subplot, and then all of the organic material within that cylinder was placed in a plastic sampling bag. Mineral soil samples $(0-10 \mathrm{~cm})$ were collected by using a $2.5 \mathrm{~cm}$ diameter stainless steel soil probe and creating a composite sample from eight subsamples within each subplot. Samples were kept on ice until returned to the laboratory for processing. Forest floor and mineral soil samples were split into two, with one portion placed in a cold chamber at $5^{\circ} \mathrm{C}$ for fresh analyses, and a second portion air dried for storage and ultimately analyzed for total $\mathrm{C}$ and $\mathrm{N}$ (forest floor and mineral soil), and for alkaline metals, $\mathrm{pH}$, particle size, water-holding capacity, and available $\mathrm{P}$ (mineral soil).

During the first sampling visit to each site (June and early July 2003), we measured extractable inorganic N, total $\mathrm{N}$, and potentially mineralizable $\mathrm{N}(\mathrm{PMN})$ in the mineral soil, and total $\mathrm{C}$ and $\mathrm{N}$ and depth of the forest floor. To determine extractable inorganic $\mathrm{N}$ content, 30 $\mathrm{g}$ of fresh sample was placed into French square bottles with $50 \mathrm{~mL}$ of $2 \mathrm{~mol} / \mathrm{L} \mathrm{KCl}$, the suspension shaken for 30 minutes, and then filtered through Whatman No. 2 filter papers (Whatman Incorporated, Florham Park, New Jersey, USA). The filtrates were then analyzed for $\mathrm{NO}_{3}{ }^{-} \mathrm{N}$ and $\mathrm{NH}_{4}{ }^{+}-\mathrm{N}$ (Mulvaney 1996) by using an Autoanalyzer III (Bran Luebbe, Chicago, Illinois, USA). Ammonium $\mathrm{N}$ was determined using the salicilate-nitroprusside method, and $\mathrm{NO}_{3}^{-}$was determined by using the cadmium reduction method (Mulvaney 1996). All fresh mineral soil samples were analyzed for potentially mineralizable $\mathrm{N}$ (PMN) using the 14-day anaerobic incubation procedure (Bundy and Meisinger 1994), where soil is analyzed for extractable $\mathrm{NH}_{4}{ }^{+}-\mathrm{N}$ as described previously. A second 5-g sample was placed into $12.5 \mathrm{~mL}$ of distilled water, and a stream of $\mathrm{N}_{2}$ gas bubbled through the suspension for one minute. The sample was then placed in a constanttemperature chamber at $25^{\circ} \mathrm{C}$ for 14 days, after which $12.5 \mathrm{~mL}$ of $4 \mathrm{~mol} / \mathrm{L} \mathrm{KCl}$ was added to the aqueous suspension to create a $2 \mathrm{~mol} / \mathrm{L} \mathrm{KCl}$ extractant, shaken for 30 minutes, and analyzed for $\mathrm{NH}_{4}{ }^{+}-\mathrm{N}$ as described above. Potentially mineralizable $\mathrm{N}$ is then estimated as the $\mathrm{NH}_{4}{ }^{+}-\mathrm{N}$ content at time 14 days minus the content at time zero. The benefit of this method is that there is no moisture limitation or excess to interfere with the incubation process. However, a limitation is that there is no nitrification step, and anaerobic mineralization may be far less efficient compared with aerobic incubation.

Dried forest floor and mineral soil samples were later analyzed for total $\mathrm{C}$ and $\mathrm{N}$ by dry combustion (Fissions EA 1100, Milan, Italy). The $\mathrm{C} / \mathrm{N}$ ratio was determined from this data by dividing the total amount of $\mathrm{C}$ by the total amount of $\mathrm{N}$. Dried mineral soils were analyzed for exchangeable alkaline metals $\left(\mathrm{Ca}^{+2}, \mathrm{Mg}^{+2}, \mathrm{~K}^{+}\right.$, and $\mathrm{Na}^{+}$), and $\mathrm{pH}$ (in a $2: 1,0.01 \mathrm{~mol} / \mathrm{L} \mathrm{CaCl}_{2}$ to soil suspension). Alkaline metals were extracted by placing $10 \mathrm{~g}$ of air-dried soil in $50 \mathrm{~mL}$ of $1 \mathrm{~mol} / \mathrm{L} \mathrm{NH} \mathrm{NCl}_{4}$ and shaking for 30 minutes. The suspensions were then filtered through Whatman No. 42 filter papers and analyzed for $\mathrm{Ca}^{+2}, \mathrm{~K}^{+}, \mathrm{Mg}^{+2}$, and $\mathrm{Na}^{+}$by inductively coupled plasma spectroscopy (Helmke and Sparks 1996, Suarez 1996). Extractable P was determined by placing $1 \mathrm{~g}$ of soil in $30 \mathrm{~mL}$ of $1 \mathrm{~mol} / \mathrm{L}$ dilute acid $\mathrm{NH}_{4} \mathrm{~F}$ and shaking for one hour. The suspensions were filtered through Whatman No. 42 filter papers and analyzed for $\mathrm{PO}_{4}{ }^{-3}$ using the molybdate-ascorbic acid method on an Autoanalyzer II as described by Kuo (1996). The remaining dried mineral soil samples were characterized for physical properties. Soil moisture content was determined gravimetrically by drying a $30-\mathrm{g}$ moist subsample at $105^{\circ} \mathrm{C}$ for 24 hours and then reweighing the sample. Particle size distribution was measured by hydrometer (Gee and Bauder 1986). Water-holding capacity was determined by measuring water content of soil samples adjusted to $-30 \mathrm{kPa}$ by using a ceramic pressure plate (Klute 1986).

In the fall of 2003 we returned to a subset of five sites (Mackay Bar and Bullion Ridge were not sampled due to inaccessibility) to further assess $\mathrm{N}$ mineralization and nitrification potentials. Wilderness restrictions prevented us from burying plastic bags or inserting polyvinyl chloride pipes; thus the majority of analyses involved soil collection in the field followed by laboratory incubations. To assess in situ mineralization and nitrification in the least obtrusive method possible, we installed spherical nylon capsules containing $1 \mathrm{~g}$ of ionic resin (Unibest, Bozeman, Montana, USA) in October 2003. Capsules were installed in the mineral soil at a depth of $10 \mathrm{~cm}$ by use of a stainless steel soil probe inserted at a $45^{\circ}$ angle. Ionic resin capsules were allowed to incubate in situ for $\sim 9$ months (fall through to summer, to include postthaw mineralization) to assess the total $\mathrm{N}$ mineralization and nitrification based on sorption of $\mathrm{NO}_{3}{ }^{-}$and $\mathrm{NH}_{4}{ }^{+}$to the ionic resin. Resin-sorbed $\mathrm{NO}_{3}{ }^{-}$and $\mathrm{NH}_{4}{ }^{+}$were determined by shaking the resin capsules with three sequential aliquots of $10 \mathrm{~mL}$ of $2 \mathrm{~mol} / \mathrm{L} \mathrm{KCl}$, decanting 
the aliquot in between samples to create a total extract volume of $30 \mathrm{~mL}$ (DeLuca et al. 2002).

Ionic resin data reflect mineral $\mathrm{N}$ that is accumulated on resins, but may not remain available for microbial immobilization. To account for $\mathrm{N}$ immobilization, we also performed an in vivo net nitrification and mineralization using a 28-day aerobic incubation. Soil samples collected following the protocol described above (four subsamples per plot and three plots per stand) using a $2.5 \mathrm{~cm}$ diameter stainless steel soil core to a depth of 10 $\mathrm{cm}$ were directly returned to the laboratory and stored at $5^{\circ} \mathrm{C}$ until they could be analyzed (within one week). Soil samples of $30 \mathrm{~g}$ were wet to $80 \%$ of water-holding capacity at $-30 \mathrm{kPa}$. A soil subsample was immediately extracted and analyzed for $\mathrm{NH}_{4}{ }^{+}-\mathrm{N}$ and $\mathrm{NO}_{3}{ }^{-} \mathrm{N}$, as described previously. A second $30-\mathrm{g}$ soil sample was placed in a $500-\mathrm{mL}$ Mason jar loosely fitted with a lid, and placed in a constant-temperature chamber at $25^{\circ} \mathrm{C}$ for 28 days; it was then extracted and analyzed for $\mathrm{NH}_{4}{ }^{+}-\mathrm{N}$ and $\mathrm{NO}_{3}{ }^{-}-\mathrm{N}$. Moisture content was checked and adjusted weekly, and 28-day net nitrification calculated as the amount of $\mathrm{NO}_{3}{ }^{-} \mathrm{N}$ at 28 days minus the $\mathrm{NO}_{3}^{-}-\mathrm{N}$ concentration at time zero; net ammonification was calculated as $\mathrm{NH}_{4}{ }^{+} \mathrm{N}$ at 28 days minus $\mathrm{NH}_{4}{ }^{+} \mathrm{N}$ at time zero, and net mineralization was calculated as the amount of total inorganic $\mathrm{N}_{\left(\mathrm{NH}_{4}{ }^{+}-\right.}$ $\mathrm{N}$ plus $\left.\mathrm{NO}_{3}{ }^{-}-\mathrm{N}\right)$ at time 28 days minus the total inorganic $\mathrm{N}$ at time zero.

To determine the nitrification potential (soil microbial potential to nitrify added $\mathrm{NH}_{4}{ }^{+}$) we used a short-term aerobic slurry assay, using the aerated slurry method (Hart et al. 1994). Soil samples of $30 \mathrm{~g}$ were placed in Erlenmeyer flasks with $100 \mathrm{~mL}$ of nutrient solution $(0.75$ $\mathrm{mmol} / \mathrm{L}\left(\mathrm{NH}_{4}\right)_{2} \mathrm{SO}_{4}, 0.3 \mathrm{mmol} / \mathrm{L} \quad \mathrm{KH}_{2} \mathrm{PO}_{4}$, and 0.7 $\mathrm{mmol} / \mathrm{L} \mathrm{K}_{2} \mathrm{HPO}_{4}$ ) with the $\mathrm{pH}$ adjusted to 7.2 , and the suspensions shaken to maintain aeration. Aliquots of 2 $\mathrm{mL}$ were removed after $0,1,2,23$, and 24 hours, diluted $1: 1$ with $4 \mathrm{~mol} / \mathrm{L} \mathrm{KCl}$ (to create a $2 \mathrm{~mol} / \mathrm{L} \mathrm{KCl}$ solution) and analyzed for $\mathrm{NO}_{3}{ }^{-} \mathrm{N}$ and the slope of the regression line describing changes in $\mathrm{NO}_{3}^{-}$with time, used to determine nitrification potential in micrograms per gram per hour.

A potential stand level difference between sites unburned and repeatedly burned in the 20th century is the presence of "active" charcoal (Zackrisson et al. 1996) in sites exposed to repeated and most recent fire. To test whether charcoal deposited during wildfire could be an important determinant of nitrification potential in these forest soils (DeLuca et al. 2002, Berglund et al. 2004, DeLuca et al. 2005), we amended soils from five of the late-succession stands (23 Mile, Whitewater Ranch, Moose Creek, Ditch Creek, and Como Lake) with field-collected charcoal (1\% mass per mass, an amount likely to be in excess of natural charcoal levels in mineral soils, but within the range of reported values) and subjected them to an aerated slurry assay (nitrification potential assay). Thus the aerated nitrification slurry assay was run with charcoal added to soils that had not been exposed to fire, and the results were compared with that of soils without charcoal added.

Data were analyzed by descriptive statistical analysis, analysis of variance, and $t$ tests. All data were evaluated for conformity to assumptions of parametric data analysis. All data not meeting these assumptions were analyzed using a nonparametric Mann-Whitney $U$ test to evaluate mean separation between paired stands of different fire history. Each pair was replicated $(n=3$, with four subsamples per replicate), and averages across all sites were replicated ( $n=7$ or 5 , depending on the response variable). This procedure created a highly conservative estimate of significance in comparison of main effects. All data were analyzed by using SPSS (2000).

\section{Description of research units}

To assist the reader, the following paragraph provides a brief guide to the terms ascribed to the various levels of research units used in this field study. Site refers to one of the seven clustered research areas spread throughout the Frank Church and Selway Bitterroot Wilderness Areas. Stand refers to a unit of the forest within a site that was subject to a given fire history. A plot is one of three, randomly placed, replicated $400-\mathrm{m}^{2}$ study units placed within a given site. Subplot is one of four $1-\mathrm{m}^{2}$ sampling units placed at a random distance (in one of four cardinal directions) from the plot center. Sample is a unit of soil (composed of multiple subsamples) collected at any one sample date that is representative of a subplot. Subsample is one of eight units of soil collected with a soil coring device from the subplot area that is used to create the composite sample.

\section{Results}

Multiple fires over the last 120 years resulted in a decrease in the total $\mathrm{N}$ concentration of the forest floor, but no significant change in mineral soil total $\mathrm{N}$ (Table 3). Stands that were unburned had an average total $\mathrm{N}$ content in the forest floor of $8.8 \mathrm{~g} / \mathrm{kg}$, compared to $6.2 \mathrm{~g} /$ $\mathrm{kg}$ in frequently burned stands. This is equivalent to $\sim 42$ $\mathrm{g} \mathrm{N} / \mathrm{m}^{2}$ in the unburned stands and $24 \mathrm{~g} \mathrm{~N} / \mathrm{m}^{2}$ in the frequently burned stands. Although this did not constitute a significant change in mineral soil total $\mathrm{N}$, stands exposed to multiple fires exhibited a significant decrease in PMN in the mineral soil (Table 3) when averaged across all seven sites. (PMN is a simple index of organic $\mathrm{N}$ available for ammonification over a 14-day anaerobic incubation.) These decreases in forest floor total $\mathrm{N}$ and mineral soil PMN were not paralleled by changes in extractable soil inorganic $\mathrm{N}$ (Table 3), as extractable $\mathrm{NH}_{4}^{+}$and $\mathrm{NO}_{3}^{-}$showed no significant or consistent trend with number of fires or time since last fire. Frequent fires during the last century did not influence total $\mathrm{C}$ in the mineral soil (data not shown), nor was there any consistent effect of fire on extractable $\mathrm{Ca}^{+2}, \mathrm{Mg}^{+2}$, or $\mathrm{K}^{+}$. Frequently burned stands had 
TABLE 3. Soil N status (mean, with SE in parentheses) in repeatedly burned stands (R) and unburned stands (U) in wilderness sites of western Montana and northern Idaho, USA.

\begin{tabular}{|c|c|c|c|c|c|}
\hline \multirow[b]{2}{*}{ Site } & \multirow[b]{2}{*}{ Burn history } & \multirow[b]{2}{*}{ Total N (g/kg) } & \multicolumn{3}{|c|}{ Forms of $\mathrm{N}(\mathrm{mg} / \mathrm{kg})$} \\
\hline & & & $\mathrm{PMN} \dagger$ & $\mathrm{NO}_{3}{ }^{-}-\mathrm{N}$ & $\mathrm{NH}_{4}^{+}-\mathrm{N}$ \\
\hline \multirow[t]{2}{*}{$23 \mathrm{M}+$} & $\mathrm{U}$ & $8.4(1.8)$ & $23.1(5.8)$ & $0.15(0.02)$ & $2.08(0.58)$ \\
\hline & $\mathrm{R}$ & $7.1(0.6)$ & $13.4(4.6)$ & $0.24(0.04)$ & $2.68(1.70)$ \\
\hline \multirow{2}{*}{ WWR } & $\mathrm{U}$ & $5.8(1.5)$ & $10.9(3.4)$ & $0.15(0.00)$ & $0.99(0.17)$ \\
\hline & $\mathrm{R}$ & $7.1(2.3)$ & $9.3(2.0)$ & $0.15(0.00)$ & $0.76(0.14)$ \\
\hline \multirow[t]{2}{*}{ MB } & $\mathrm{U}$ & $9.2(1.8)$ & $24.5(4.9)$ & $0.23(0.09)$ & $0.90(0.17)$ \\
\hline & $\mathrm{R}$ & $3.7(1.2)^{* *}$ & $23.9(4.8)$ & $0.55(0.22)^{*}$ & $0.74(0.20)$ \\
\hline \multirow[t]{2}{*}{$\mathrm{CL}$} & $\mathrm{U}$ & $12.1(3.4)$ & $56.7(29.4)$ & $0.23(0.01)$ & $2.90(0.86)$ \\
\hline & $\mathrm{R}$ & $7.1(1.3)^{*}$ & $11.1(4.5)^{*}$ & $0.20(0.01)$ & $0.84(0.24)^{*}$ \\
\hline \multirow[t]{2}{*}{$\mathrm{BR}$} & $\mathrm{U}$ & $9.9(2.0)$ & $25.6(6.1)$ & $0.23(0.00)$ & $1.36(0.40)$ \\
\hline & $\mathrm{R}$ & $4.7(1.4)^{* *}$ & $18.6(3.7)$ & $0.32(0.18)$ & $1.11(0.34)$ \\
\hline \multirow[t]{2}{*}{ DC } & $\mathrm{U}$ & $8.4(1.8)$ & $15.0(6.6)$ & $0.20(0.08)$ & $0.69(0.30)$ \\
\hline & $\mathrm{R}$ & 8.0 (1.9) & $22.0(5.2)$ & $0.20(0.06)$ & $0.84(0.18)$ \\
\hline \multirow[t]{2}{*}{$\mathrm{MC}$} & $\mathrm{U}$ & $6.0(1.2)$ & $22.8(6.4)$ & $0.20(0.09)$ & $1.27(0.36)$ \\
\hline & $\mathrm{R}$ & $4.7(0.8)$ & $11.8(4.0)^{*}$ & $0.15(0.00)$ & $0.93(0.22)$ \\
\hline \multirow{2}{*}{ Mean } & $\mathrm{U}$ & $8.7(1.4)$ & $25.3(2.2)$ & $0.20(0.03)$ & $1.47(0.14)$ \\
\hline & $\mathrm{R}$ & $5.5(1.0)^{*}$ & $17.2(3.6) *$ & $0.26(0.08)$ & $1.25(0.09)$ \\
\hline
\end{tabular}

Notes: See Table 1 for site codes, fire dates, and methods. Values from the unburned or multiple-burn stands that are significantly different as determined by Mann-Whitney $U$ tests are designated as follows: $* P<0.05 ; * * P<0.01$.

$\dagger$ Potentially mineralizable N.

\$ At 23M what we had initially identified as an unburned site (unburned since 1910) had in fact burned in 1910 and 1934 , and the three-burn site burned one additional time, in 1992.

significantly higher soil $\mathrm{pH}$ when averaged across sites compared to unburned stands (Table 4).

Net mineralization and nitrification results from $28-$ day aerobic laboratory incubations did not corroborate the PMN results. While there was no significant effect of fire frequency on net ammonification (Fig. 1a), we did observe a significant increase in net nitrification (Fig. 1b) and net mineralization (Fig 1c; sum of net $\mathrm{NO}_{3}{ }^{-}$and $\mathrm{NH}_{4}{ }^{+}$accumulation over a 28-d period) in frequently burned stands relative to unburned stands. These results were further corroborated by in situ monitoring of nitrification by measuring $\mathrm{NO}_{3}{ }^{-}$and $\mathrm{NH}_{4}{ }^{+}$sorption to ionic resin capsules. While there was no trend for $\mathrm{NH}_{4}{ }^{+}$ accumulation on ionic resins, $\mathrm{NO}_{3}^{-}$accumulation was significantly greater in frequently burned stands, suggesting that nitrification in the field was also higher in these stands relative to unburned stands (Fig. 2). The sum of $\mathrm{NO}_{3}{ }^{-}$and $\mathrm{NH}_{4}{ }^{+}$accumulation (in situ mineralization) on ionic resins did not reflect an increase in net mineralization over the past 120 years as a result of multiple fires. Nitrification potential (as measured by a 24-hour aerated soil slurry method) was also significantly greater in soils from sites exposed to multiple fires compared to those not exposed to fire when averaged across all sites (Fig. 3).

TABLE 4. Exchangeable alkaline metal concentrations $(\mathrm{mg} / \mathrm{kg}$ ) and soil $\mathrm{pH}$ (mean, with sE in parentheses) in repeatedly burned ( $\mathrm{R})$ and unburned (U) stands in wilderness areas of western Montana and northern Idaho, USA.

\begin{tabular}{lccccc}
\hline \hline Site & Burn history & $\mathrm{Ca}^{+2}$ & $\mathrm{Mg}^{+2}$ & $\mathrm{~K}^{+}$ & $\mathrm{pH}$ \\
\hline $23 \mathrm{M}$ & $\mathrm{U}$ & $240(16)$ & $21(2)$ & $31(4)$ & $4.3(0.3)$ \\
& $\mathrm{R}$ & $239(30)$ & $19(2.8)$ & $39(8)$ & $4.8(0.3)$ \\
WWR & $\mathrm{U}$ & $261(15)$ & $32(5.8)$ & $46(7)$ & $5.0(0.2)$ \\
& $\mathrm{R}$ & $222(16)$ & $22(2.2)^{*}$ & $39(8)$ & $5.2(0.2)$ \\
MB & $\mathrm{U}$ & $826(230)$ & $120(33)$ & $268(69)$ & $4.8(0.2)$ \\
& $\mathrm{R}$ & $257(33)^{*}$ & $28(5)^{*}$ & $62(13)^{*}$ & $5.2(0.1)^{*}$ \\
$\mathrm{CL}$ & $\mathrm{U}$ & $476(182)$ & $35(14)$ & $87(29)$ & $4.8(0.2)$ \\
& $\mathrm{R}$ & $460(227)$ & $49(32)$ & $147(111)$ & $4.9(0.3)$ \\
BR & $\mathrm{U}$ & $303(42)$ & $25(4.3)$ & $76(16)$ & $4.5(0.3)$ \\
& $\mathrm{R}$ & $1008(107)^{*}$ & $246(40)^{*}$ & $4.5(0.2)$ \\
DC & $\mathrm{U}$ & $358(18)$ & $26(4)$ & $41(9)$ & $4.8(0.2)$ \\
& $\mathrm{R}$ & $400(228)$ & $49(7)$ & $70(6)$ & $4.9(0.3)$ \\
MC & $\mathrm{U}$ & $201(26)$ & $16(3.2)$ & $33(6)$ & $4.4(0.4)$ \\
& $\mathrm{R}$ & $387(38)$ & $42(24)$ & $85(51)$ & $5.0(0.2)$ \\
Mean & $\mathrm{U}$ & $386(41)$ & $46(27)$ & $84(52)$ & $4.6(0.1)$ \\
& $\mathrm{R}$ & & $4.9(0.2)^{*}$ \\
\hline
\end{tabular}

Notes: Values from the unburned or multiple-burn stands that are significantly different as determined by Mann-Whitney $U$ tests are designated by asterisks: $(n=3$ soil replicates, with the value averaged from four subsamples for individual sites and $n=7$ for the mean across all sites).

$$
* P<0.05 \text {. }
$$



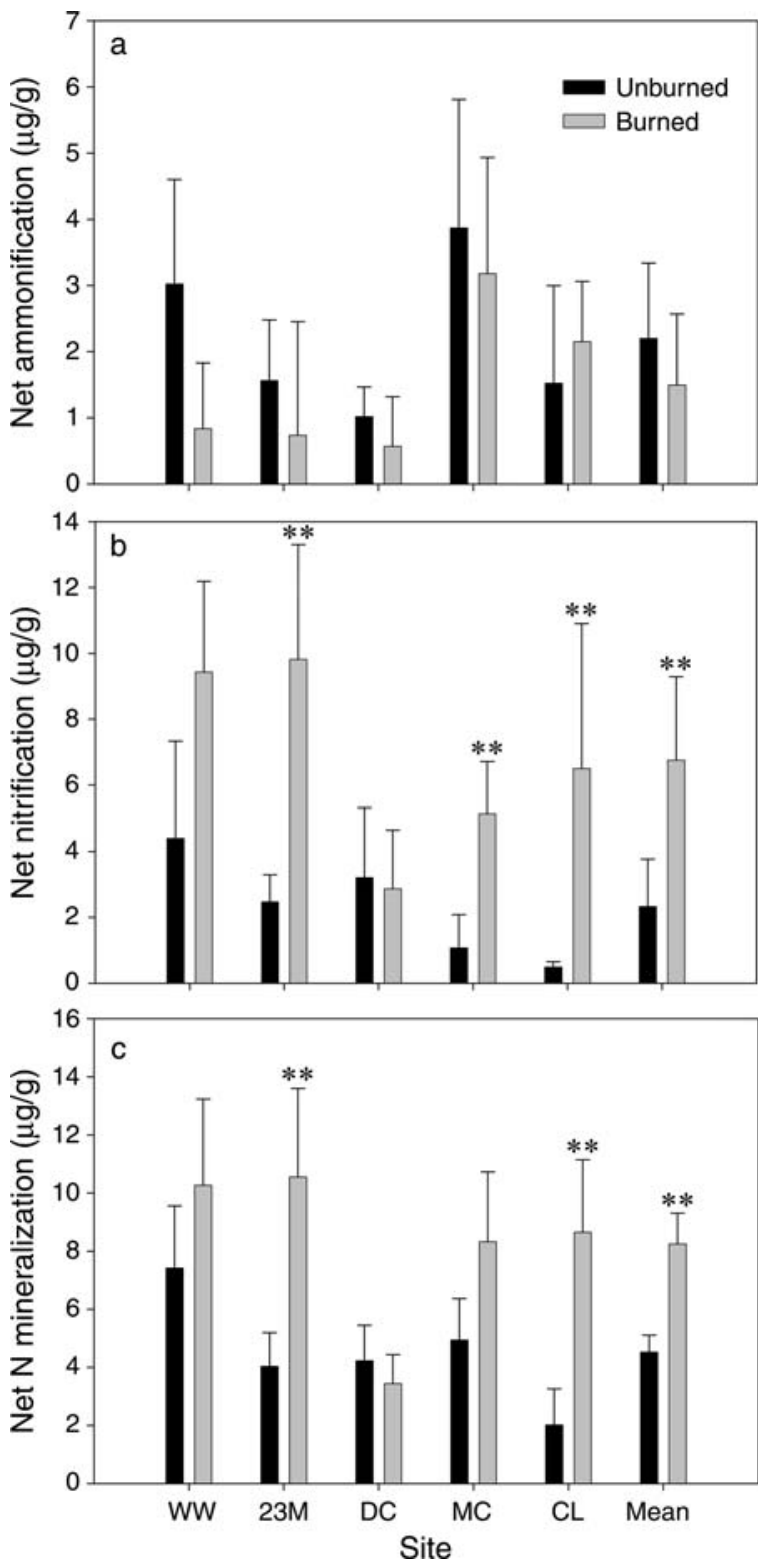

FIG. 1. (a) Net ammonification, (b) net nitrification, and (c) net mineralization (mean $+\mathrm{SE}, n=3$ soil replicates) as determined using an aerobic 28 -d incubation for soils collected from repeatedly burned and unburned stands in wilderness areas of western Montana and northern Idaho, USA (see Methods; for full site names, see Table 1). Asterisks denote significant differences between burned and unburned stands, as determined by Mann-Whitney $U$ tests.

$* * P<0.01$.

Soils amended with charcoal from three of the sites exhibited a significant increase in nitrification potential similar to that of fire-exposed soils (Fig. 4). Nitrification potential averaged across all five soils amended with charcoal was significantly greater than with no charcoal added. Note that this was only a 24-hour assay, and therefore the response observed is extremely rapid.

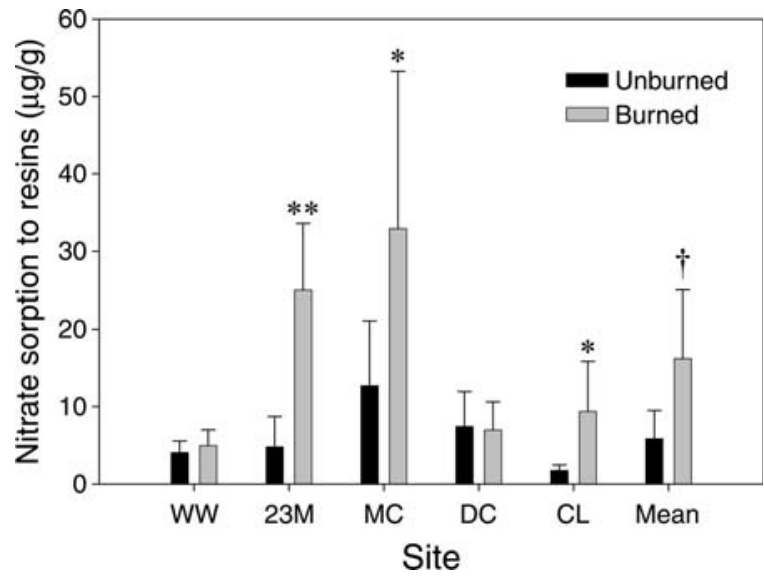

FIG. 2. Sorption of $\mathrm{NO}_{3}^{-}-\mathrm{N}$ to ionic resin capsules (mean + $\mathrm{SE}, n=3$ resin replicates) buried $10 \mathrm{~cm}$ deep in the mineral soil of repeatedly burned and unburned stands in wilderness areas of western Montana and northern Idaho, USA. (For full site names, see Table 1.) Symbols above bars indicate significant differences between burned and unburned stands, as determined by Mann-Whitney $U$ tests.

${ }^{*} P<0.05 ; * * P<0.01 ; \dagger P<0.1$.

\section{DisCUSSION}

Based on results from several undisturbed sites across two wilderness areas in mixed ponderosa pine systems of the northern Rocky Mountains, we show for the first time a significant decrease in inorganic $\mathrm{N}$ availability in stands not subjected to fire in the past 69-130 years relative to stands burned 2-4 times during the same period. Such a decrease was supported by lower $\mathrm{NO}_{3}{ }^{-}$ adsorption to ionic resin capsules in the field, and decreased nitrification potential and net nitrification in laboratory assays. These data support the largely untested hypothesis that exclusion of fire in short-

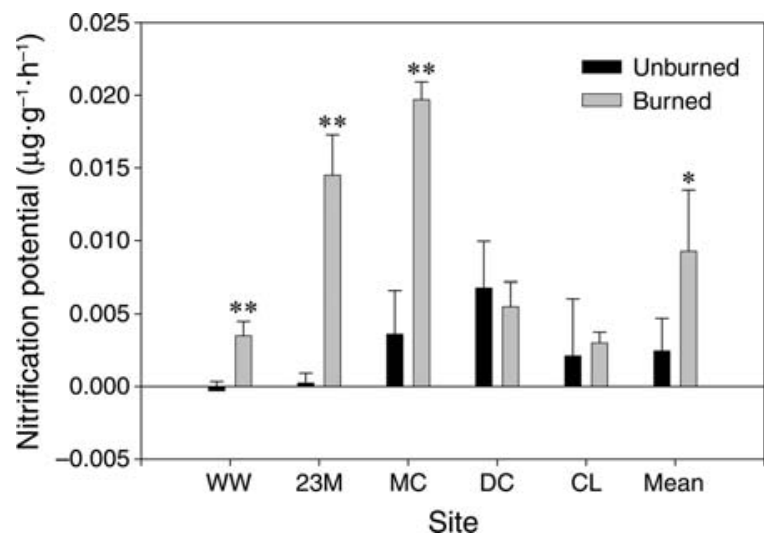

FIG. 3. Nitrification potential (mean $+\mathrm{sE}, n=3$ soil replicates) as estimated using an aerated soil slurry method for soils collected from repeatedly burned and unburned stands in wilderness areas of western Montana and northern Idaho. (For full site names, see Table 1.) Symbols above bars indicate significant differences between burned and unburned stands, as determined by Mann-Whitney $U$ tests.

$* P<0.05 ; * * P<0.01$. 
interval, fire-dependent ponderosa pine ecosystems results in a decrease of inorganic $\mathrm{N}$ availability (Covington and Sackett 1992).

Our results also point to the role of charcoal in maintaining nitrification in frequently burned stands long after the direct impacts (e.g., heat pulse) of fire have abated. These results are important because, in contrast to previous studies showing rapid, but short-lived, increases in ammonium immediately after fire in ponderosa pine systems (Wright and Hart 1997, Kaye and Hart 1998, DeLuca and Zouhar 2000), they reflect a long-term effect of recurrent, natural fire on N-cycling properties. Differences in inorganic $\mathrm{N}$ availability and transformation rates and associated changes in soil chemical and biological properties between frequently burned and unburned ponderosa pine ecosystems may influence establishment and subsequent successional dynamics. While the gradual replacement of ponderosa pine by Douglas-fir in mixed ponderosa pine ecosystems in the absence of fire is attributed to the increased shade tolerance by the latter, changes in $\mathrm{N}$ cycling and availability may also influence successional dynamics (see Plate 1).

Differences in $\mathrm{N}$ availability between frequently burned and unburned stands did not relate to significant changes in several soil chemical and physical characteristics. For instance, soil extractable metal content was not influenced by fire frequency. It is commonly thought that fire increases the presence of available alkaline metals, as they are not volatilized at the surface temperatures reached in most forest fire events (Neary et al. 1999, Bélanger et al. 2004, Certini 2005). It is possible that the long time elapsed since the last fire in the fire-maintained stands at our sites (between 11 and 16 years) reduced the expected differences in extractable metals. However, on a site by site basis, there was little difference in alkaline metal concentrations, even at those sites exposed to fire within the last 12 years. The lack of differences in alkaline metal concentrations with fire history may also relate to the relatively immature nature of soils of this region, resulting in relatively high concentrations of alkaline metals at all of the sites. In contrast, alkaline-metal-poor soils of Southern Ohio experience a significant increase in exchangeable $\mathrm{Ca}^{+2}$ concentrations following reestablished fire intervals in mixed oak (Quercus spp.). Averaged across the seven sites, we observed a significant increase in soil $\mathrm{pH}$ on sites exposed to multiple fire events (Table 4). Consistent with the lack of difference in alkaline metal concentration, however, the differences in $\mathrm{pH}$ were probably too small to be of biological importance.

While mineral soil nitrification increased in frequently burned stands, recurrent multiple fires over the past 69 130 year period resulted in a net loss of total $\mathrm{N}$ capital. The decline in forest floor $\mathrm{N}$ concentration and content (amount per unit area) suggests that the amount of organic $\mathrm{N}$ volatilized during fire is not recovered in the forest floor during the interval between fire events. In the

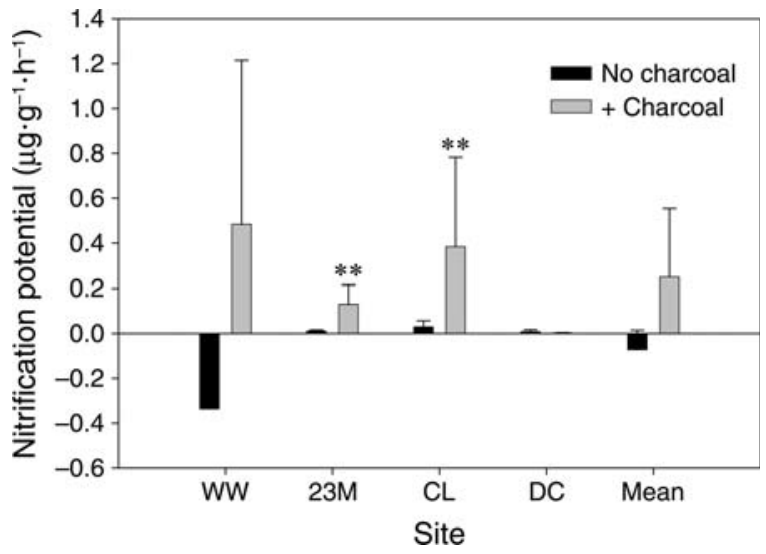

FIG. 4. Nitrification potential (mean $+\mathrm{SE}, n=3$ soil replicates) as influenced by the addition of field-collected charcoal in soils from several study sites with unburned stands or stands exposed to two or more fires over the past $69-130$ years in wilderness areas of western Montana and northern Idaho. (For full site names, see Table 1.) Asterisks above bars indicate significant differences between stands with and without addition of charcoal, as determined by Mann-Whitney $U$ tests.

$* * P<0.01$.

mineral soil, however, frequent fire did not reduce total C and N (see also Smithwick et al. 2005), supporting the fact that mineral soil $\mathrm{C}$ and $\mathrm{N}$ pools are very stable and not directly influenced by fire (Neary et al. 1999, Certini 2005). The decline in mineral soil PMN with the occurrence of multiple fires may be somewhat counterintuitive, given that $\mathrm{NO}_{3}^{-}$availability increased. However, these data reflect a long-term effect of frequent fire (more than a decade after fire), whereby increased nitrification of labile $\mathrm{N}$ after multiple fire events could reduce $\mathrm{PMN}$ in the long term. Our results are consistent with those of Prieto-Fernandez et al. (2004) and Ferran et al. (2005) for other forest ecosystems. Interestingly, earlier work from the Inland Northwest also showed that mineralizable N (Monleon et al. 1997) and PMN (Newland and DeLuca 2000) may be reduced by the reintroduction of a single fire after years of fire exclusion. The basis for this short-term reduction in PMN, however, may reflect the combustion of accumulated labile $\mathrm{N}$ pools. The fact that higher $\mathrm{NO}_{3}{ }^{-}$sorbed in resin capsules was not paralleled by differences in extractable $\mathrm{NH}_{4}{ }^{+}$and $\mathrm{NO}_{3}{ }^{-}$is to be expected given the variable nature of these forms of inorganic N. Although differences in inorganic $\mathrm{N}$ are commonly observed within the first two years following fire (see Smithwick et al. 2005), it is rare to observe increases in extractable inorganic N 5-20 years after fire (the range in time since most recent fire used in this study).

Individual indices or measures of available $\mathrm{N}$ may be misleading when taken out of context (see Schimel and Bennett 2004); thus we attempted to address net $\mathrm{N}$ mineralization and nitrification using both field and laboratory incubations. While PMN was found to generally decrease with frequent fire, net $\mathrm{N}$ nitrification 

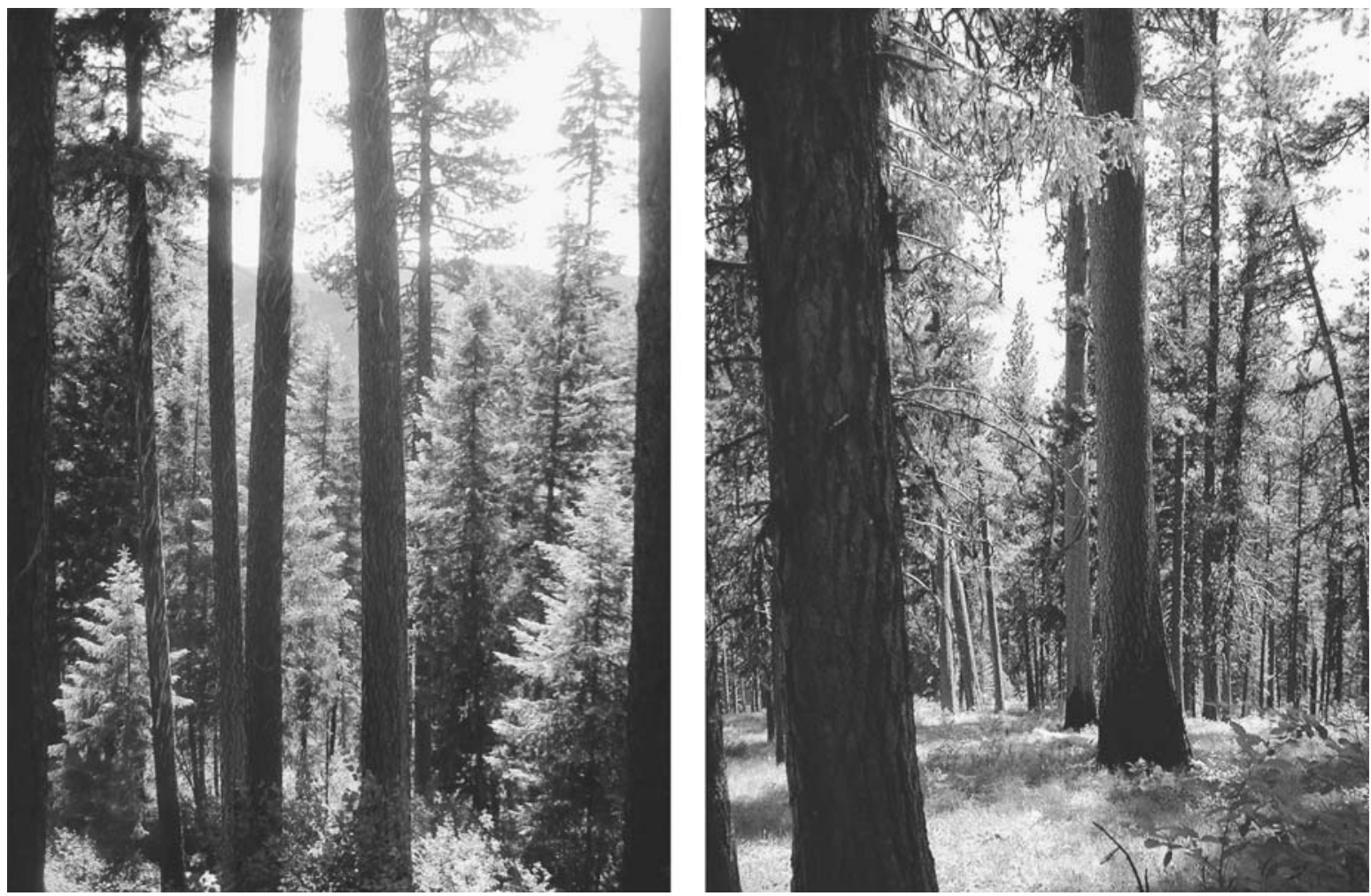

Plate 1. Two stands of ponderosa pine in the Frank Church River of No Return wilderness that were (left, at MacKay Bar) not exposed to fire in the past 100 years (note the increase in Douglas-fir) and (right, near White Water Ranch) subject to repeated fires (note the fire scars in the old-growth trees) during this same time period. Canopy dominant trees were approximately 250 years old in both stands. Photo credits: left, A. Sala; right, Eric Keeling.

in aerobic laboratory incubations, nitrification potential (24-hour aerated slurry assay), and accumulation of $\mathrm{NO}_{3}{ }^{-}$on ionic resins (in situ measure of $\mathrm{N}$ mineralization and nitrification) all consistently demonstrated an increasing trend in frequently burned stands. Furthermore, gross nitrification (D. M. MacKenzie and T. H. DeLuca, unpublished data) rates at one site $(23 \mathrm{M})$ were found to be notably higher in burned than unburned stands in spite of the fact that the "unburned" stand had been exposed to low-severity fire in 1910 and 1934. It is well established that individual fire events (see Smithwick et al. 2005), repeated prescribed fire (Wright and Hart 1997), and simple soil-heating events (Choromanska and DeLuca 2002) stimulate short-term increases in net nitrification for forest soils. Our results demonstrate a much greater long-term change in $\mathrm{N}$ cycling properties as a result of differences in fire frequency. These findings are consistent with fire chronosequence studies showing elevated $\mathrm{NO}_{3}{ }^{-} \mathrm{N}$ accumulation on ionic resins in sites exposed to fire during the last 3-17 years prior to sampling in both boreal forests of northern Sweden (DeLuca et al. 2002) and ponderosa pine forests of the Inland Northwest (MacKenzie et al. 2005).

Several possible mechanisms may explain why nitrification declines in the absence of fire, including: (1) decreased substrate quality resulting in depressed rates of ammonification; (2) increased rates of amino- $\mathrm{N}$ and $\mathrm{NH}_{4}{ }^{+}$fixation into polyphenol complexes; (3) increased availability of $\mathrm{C}$ substrate resulting in rapid immobilization of $\mathrm{NH}_{4}^{+}$and $\mathrm{NO}_{3}^{-}$; (4) accumulation of compounds inhibitory to the process of nitrification.

Multiple low-severity fires over the past century may have reduced the recalcitrant $\mathrm{N}$ pool and perhaps the presence of polyphenolic- $\mathrm{N}$ compounds that would otherwise interfere with net release of inorganic $\mathrm{N}$, thereby enhancing net nitrification (Northup et al. 1995, Hättenschwiler and Vitousek 2000, Fierer et al. 2001). The fact that relatively high rates of gross nitrification have been observed in forest soils regardless of stand maturity suggest that the lack of $\mathrm{NO}_{3}{ }^{-}-\mathrm{N}$ accumulation in late succession is a function of rapid immobilization of $\mathrm{NO}_{3}{ }^{-}-\mathrm{N}$ (Stark and Hart 1997). Although we have not observed significant increases in available $\mathrm{C}$ in mineral soils with time since fire (see also MacKenzie et al. 2005), it is possible that increases in soluble phenols in the forest floor with time since fire (MacKenzie et al. 2004) result in greater $\mathrm{N}$ immobilization rates (e.g., Schimel et al. 1996). There is also evidence to suggest that compounds inhibitory to the process of nitrification (Lohdi and Killingbeck 1980, White 1991, Ward et al. 1997, Paavolainen et al. 1998) accumulate over time in the absence of fire. Multiple fires during the past century 
would have acted to reduce the presence of volatile inhibitory compounds.

Deposition of charcoal during fire events may function to adsorb compounds that might otherwise inhibit nitrification, and induce the fixation of $\mathrm{NH}_{4}{ }^{+}$or immobilization of $\mathrm{NH}_{4}^{+}$or $\mathrm{NO}_{3}^{-}$(Zackrisson et al. 1996, Pietekäinen et al. 2000, DeLuca et al. 2002, Berglund et al. 2004, Wardle et al. 2004, DeLuca et al. 2005). The significant and immediate increase in nitrification potential of unburned soils amended with charcoal from repeatedly burned stands provides evidence of the importance of charcoal activity in mineral soils. These results support incubation experiments and isotope dilution studies involving soils from late-succession field sites, clearly demonstrating that the presence of charcoal in mineral soils acts to enhance net nitrification (DeLuca et al. 2005). Charcoal deposited during fires may partially fill the role of humus in these soils, which are otherwise poor in organic matter, thereby increasing soil buffering, sorption, and waterholding capacity (e.g., Glaser et al. 2002).

A decline in the nitrification potential of mineral soils in the absence of fire may have implications for plant species composition, as preferences for $\mathrm{N}$ forms are species specific and may depend on successional status (Haines 1977, Kronzucker et al. 1997, Persson et al. 2003). The relative preferences of specific $\mathrm{N}$ forms by ponderosa pine and Douglas-fir, particularly at young life stages, are unknown. If these preferences were different, our results could have important implications for successional stand development in this system. If ponderosa pine seedlings that are in process of establishment preferentially take up $\mathrm{NO}_{3}^{-}-\mathrm{N}$, a more soluble and highly mobile form of $\mathrm{N}$ available to plants, their recruitment may be limited later in succession as $\mathrm{N}$ availability declines. We did not observe a significant change in understory species composition in the absence of fire (E. Keeling, A. Sala, and T. H. DeLuca, unpublished manuscript), as is often observed in pure ponderosa pine stands of the southwestern United States (e.g., Covington and Moore 1994b). Therefore, changes in soil organic matter characteristics in the absence of fire in these inland Northwestern forests include increased depth of the forest floor (Oi, Oe, and $\mathrm{Oa}$ horizons), lack of deposition of fresh charcoal, and potential changes in litter quality that likely result from a significant increase in the later successional, more shade-tolerant Douglas-fir (E. Keeling, A. Sala, and T. H. DeLuca, unpublished manuscript). Relative to faster growing, shade-intolerant early-successional species, shade-tolerant, later successional species tend to be longer lived (Loehle 1988) and produce lower quality litter. This is because as succession proceeds and nutrients become tied up in biomass (Hunt et al. 1988), plants respond to increasing nutrient limitations with strategies that minimize nutrient losses with the production of low-quality litter (Aerts and Chapin 2000, Hart et al. 2005). Such low-quality, low-N litter would enhance rates of $\mathrm{N}$ immobilization and potentially fixation of $\mathrm{NH}_{4}{ }^{+}$into protein polyphenol complexes. Late-succession dominant species have been shown to prefer $\mathrm{NH}_{4}^{+}$(Haines 1977, Kronzucker et al. 1997) or amino-N (Persson et al. 2003), which must arrive at the root surface by diffusion or root interception (root or mycorrhizal) rather than mass flow. It is not known if this is the case for shade-tolerant species common in mixed ponderosa pine forests. If differential uptake of $\mathrm{N}$ forms exists between ponderosa pine and other common shade-tolerant species, then in addition to shade, the increase in $\mathrm{NO}_{3}^{-}-\mathrm{N}$ availability in frequently burned stands relative to unburned stands may contribute to the successional dynamics of these systems.

\section{Conclusions}

Our work clearly shows that repeated fires during the 20th century reduced soil $\mathrm{N}$ capital and increased net nitrification relative to stands unburned for almost seven decades or more. Higher $\mathrm{NO}_{3}{ }^{-}$measured in ionic resin capsules provides compelling evidence for increased nitrification at sites with a natural fire return interval. The increase in nitrification and nitrification potential in laboratory assays further suggests that indirect, longterm effects of fire (e.g., shifts in litter quality and deposition of charcoal causing altered soil solution chemistry) are important determinants of $\mathrm{N}$ dynamics. Results of the addition of charcoal to late-succession soils suggest an important function for naturally deposited charcoal in forest ecosystems. While the specific mechanisms by which $\mathrm{NO}_{3}^{-}$availability increases in frequently burned stands relative to unburned stand are not known, our results suggest that available $\mathrm{N}$ forms change during succession. The accessibility of $\mathrm{N}$ in various forms, in addition to changes in light availability, may contribute to species establishment and successional dynamics. This study corroborates the long-standing but untested hypothesis that lack of fire in fire-dependent ponderosa pine systems results in a decrease of $\mathrm{N}$ availability, and underscores the value of research in natural, remote areas.

\section{ACKNOWLEDGMENTS}

Special thanks to Brett Davis and Carol Miller from the Aldo Leopold Wilderness Research Institute (Missoula, Montana) for assembling the GIS database that allowed us to identify sampling sites. The authors thank numerous individuals for support in the field and the laboratory, including Rachel Brimmer, Valerie Kurth, Eric Keeling, Kate Finnegan, Derek MacKenzie, Lorna McIntyre, Mara Saccoccia, Lauren Priestman, and Alicia Michels. This project was supported by a National Research Initiative Competitive Grant No. 200235107-12267 from the USDA Cooperative State Research, Education, and Extension Service and from the USDA Leopold Wilderness Research Institute (Forest Service Rocky Mountain Research Station) ALWRI-4901.

\section{Literature Cited}

Aerts, R., and F. S. Chapin. 2000. The mineral nutrition of wild plants revisited: a re-evaluation on processes and patterns. Advances in Ecological Research 30:1-67. 
Allen, C. D., J. L. Betancourt, and T. W. Swetnam. 1998. Landscape changes in the southwestern United States: techniques, long-term data sets, and trends. Pages 71-84 in T. D. Sisk, editor. Perspectives on the land-use history of North America: a context for understanding our changing environment. U.S. Geological Survey, Fort Collins, Colorado, USA.

Allen, C. D., M. Savage, D. A. Falk, K. F. Suckling, T. W. Swetnam, T. Schulke, P. B. Stacey, P. Morgan, M. Hoffman, and J. T. Klingel. 2002. Ecological restoration of Southwestern ponderosa pine ecosystems: a broad perspective. Ecological Applications 12:1418-1433.

Arno, S. F., and S. Allison-Bunnell. 2002. Flames in our forest: disaster or renewal? Island Press, Seattle, Washington, USA.

Arno, S. F., J. H. Scott, and G. H. Hartwell. 1995. Age-class structure of old growth Ponderosa pine/Douglas-fir stands and its relationship to fire history. USDA Forest Service Intermountain Research Station Research Report INT-RP481, Ogden, Utah, USA.

Barrett, S. W., S. F. Arno, and C. H. Key. 1991. Fire regimes of western larch-lodgepole pine forests in Glacier National Park, Montana. Canadian Journal of Forest Research 21: $1711-1720$.

Bélanger, N. I., B. Côté, J. W. Fyles, F. Chourchesne, and W. H. Hendershot. 2004. Forest regrowth as the controlling factor of soil nutrient availability 75 years after fire in a deciduous forest of southern Quebec. Plant and Soil 262:363372.

Berglund, L., T. H. DeLuca, and O. Zackrisson. 2004. Activated carbon amendments to soil alters nitrification rates in Scots pine forests. Soil Biology and Biochemistry 36: 2067-2073.

Brown, P. M., M. R. Kaufmann, and W. D. Shepperd. 1999. Long-term landscape patterns of past fire events in a montane ponderosa pine forest of central Colorado. Landscape Ecology 14:513-532.

Bundy, L. G., and J. J. Meisinger. 1994. Nitrogen availability indices. Pages 951-984 in R. W. Weaver, S. Angle, and P. Bottomly, editors. Methods of soil analysis. Part 2: Microbiological and biochemical properties. Soil Science Society of America, Madison, Wisconsin, USA.

Certini, G. 2005. Effects of fire on properties of forest soils: a review. Oecologia 143:1-10.

Choromanska, U., and T. H. DeLuca. 2001. Prescribed fire alters the effect of wildfire on soil biochemical properties in a ponderosa pine forest. Soil Science Society of America Journal 65:232-238

Choromanska, U., and T. H. DeLuca. 2002. Microbial activity and nitrogen mineralization in forest mineral soils following heating: evaluation of post-fire effects. Soil Biology and Biochemistry 34:263-271.

Covington, W. W., P. Z. Fulé, M. M. Moore, S. C. Hart, T. E. Kolb, J. N. Mast, S. S. Sackett, and M. R. Wagner. 1997. Restoration of ecosystem health in southwestern ponderosa pine forests. Journal of Forestry 95:23-29.

Covington, W. W., and M. M. Moore. 1994a. Southwestern ponderosa pine forest structure and resource conditions: changes since Euro-American settlement. Journal of Forestry 92(1):39-47.

Covington, W. W., and M. M. Moore. 1994b. Postsettlement changes in natural fire regimes and forest structure: ecological restoration of old-growth ponderosa pine forests. Journal of Sustainable Forestry 2:153-181.

Covington, W. W., and S. S. Sackett. 1992. Soil mineral nitrogen changes following prescribed burning in ponderosa pine. Forest Ecology and Management 54:175-191.

DeLuca, T. H., M. D. MacKenzie, M. J. Gundale, and W. E. Holben. 2005. Charcoal directly influences nitrification in forest soils. Soil Science Society of America Journal, in press.

DeLuca, T. H., M-C. Nilsson, and O. Zackrisson. 2002. Nitrogen mineralization and phenol accumulation along a fire chronosequence in northern Sweden. Oecologia 133:206214.

DeLuca, T. H., and K. L. Zouhar. 2000. Effect of selection cutting and prescribed fire on $\mathrm{N}$ dynamics in ponderosa pine forests. Forest Ecology and Management 138:263-271.

Feeney, S. R., T. E. Kolb, W. W. Covington, and M. R. Wagner. 1998. Influence of thinning and burning restoration treatments on presettlement ponderosa pine at the Gus Pearson Natural Area. Canadian Journal of Forest Research 28:1295-1306.

Ferran, A., W. Delitti, and V. R. Vallejo.. 2005. Effects of fire recurrence in Quercus coccifera L. shrublands of the Valencia Region (Spain): II. plant and soil nutrients. Plant Ecology 177:71-83.

Fierer, N., J. P. Schimel, R. G. Cates, and J. Zou. 2001. Influence of balsam poplar tannin fractions on carbon and nitrogen dynamics in Alaskan taiga floodplain soils. Soil Biology and Biochemistry 33:1827-1839.

Fulé, P. Z., W. W. Covington, and M. M. Moore. 1997. Determining reference conditions for ecosystem management of southwestern ponderosa pine forests. Ecological Applications 7:895-908.

Gee, G. W., and J. W. Bauder. 1986. Particle-size analysis. Pages 383-412 in A. Klute, editor. Methods of soil analysis. Part 1: Physical and mineralogical properties. Soil Science Society of America, Madison, Wisconsin, USA.

Glaser, B., J. Lehmann, and W. Zech. 2002. Ameliorating physical and chemical properties of highly weathered soils in the tropics with charcoal - a review. Biology and Fertility of Soils 35:219-230.

Gruell, G. E. 1983. Fire and vegetative trends in the Northern Rockies: interpretations from 1871-1982 photographs. USDA Forest Service Intermountain Forest and Range Experiment Station General Technical Report GTR-INT-158, Ogden, Utah, USA.

Gundale, M. J., T. H. DeLuca, C. E. Fiedler, P. W. Ramsey, M. G. Harrington, and J. E. Gannon. 2005. Restoration management in a Montana ponderosa pine forest: effects on soil physical, chemical and biological properties. Forest Ecology and Management 205:25-38.

Haines, B. L. 1977. Nitrogen uptake apparent pattern during old field succession in southeastern USA. Oecologia 26:295304.

Hart, S. C., T. H. DeLuca, G. S. Newman, M. D. MacKenzie, and S. I. Boyle. 2005. Post-fire vegetative dynamics as drivers of microbial community structure and function in forest soils. Forest Ecology and Management 220:66-184.

Hart, S. C., J. M. Stark, E. A. Davidson, and M. K. Firestone. 1994. Nitrogen mineralization, immobilization, and nitrification. Pages 985-1018 in R. W. Weaver, S. Angle, and P. Bottomly, editors. Methods of soil analysis. Part 2: Microbiological and biochemical properties. Soil Science Society of America, Madison, Wisconsin, USA.

Hättenschwiler, S., and P. M. Vitousek. 2000. The role of polyphenols in terrestrial ecosystem nutrient cycling. Trends in Ecology and Evolution 15:238-243.

Helmke, P. A., and D. L. Sparks. 1996. Lithium, sodium, potassium, rubidium, and cesium. Pages $551-574$ in D. L. Sparks, editor. Methods of soil analysis. Part 3: Chemical methods. SSSA Book Series 5. Soil Science Society of America, Madison, Wisconsin, USA.

Hunt, H. W., E. R. Ingham, D. C. Coleman, E. T. Elliott, and C. P. P. Reid. 1988. Nitrogen limitation of production and decomposition in prairie, mountain meadow, and pine forest. Ecology 69:1009-1016.

Kaufmann, M. R., C. M. Regan, and P. M. Brown. 2000. Heterogeneity in ponderosa pine/Douglas-fir forests: age and size structure in unlogged and logged landscapes of central Colorado. Canadian Journal of Forest Research 30: 698-711. 
Kaye, J. P., and S. C. Hart. 1998. Ecological restoration alters nitrogen transformations in a ponderosa pine-bunchgrass ecosystem. Ecological Applications 8:1052-1060.

Keane, R. E., R. A. Parsons, and P. F. Hessburg. 2002. Estimating historical range and variation of landscape patch dynamics: limitations of the simulation approach. Ecological Modeling 151:29-49.

Klute, A. 1986. Water retention: laboratory methods. Pages 635-662 in A. Klute, editor. Methods of soil analysis. Part 1: Physical and mineralogical properties. Soil Science Society of America, Madison, Wisconsin, USA.

Kronzucker, H. J., M. Y. Siddiqi, and A. D. M. Glass. 1997. Conifer root discrimination against soil nitrate and the ecology of forest succession. Nature 385:50-61.

Kuo, S. 1996. Phosphorus. Pages 896-919 in D. L. Sparks, editor. Methods of soil analysis. Part 3: Chemical methods. SSSA Book Series 5. Soil Science Society of America, Madison, Wisconsin, USA.

Loehle, C. 1988. Tree life history strategies: the role of defenses. Canadian Journal of Forest Research 18:209-222

Lohdi, M. A. K., and K. T. Killingbeck. 1980. Allelopathic inhibition of nitrification and nitrifying bacteria in a ponderosa pine (Pinus ponderosa Dougl.) community. American Journal of Botany 67:1423-1429.

MacKenzie, D. M., T. H. DeLuca, and A. Sala. 2004. Forest structure and organic matter analysis along a fire chronosequence in the low elevation forests of western Montana. Forest Ecology and Management 203:331-343.

MacKenzie, D. M., T. H. DeLuca, and A. Sala. 2005. Nitrogen mineralization and biodiversity in low elevation forests of western Montana. Soil Biology and Biochemistry, in press.

Mandzak, J. M., and J. A. Moore. 1994. The role of nutrition in the health of inland western forests. Journal of Sustainable Forestry 2:191-210.

Mast, J. N., P. Z. Fulé, M. M. Moore, W. W. Covington, and A. E. M. Waltz. 1999. Restoration of presettlement age structure of an Arizona ponderosa pine forest. Ecological Applications 9:228-239.

Monleon, V. J., K. Cromack, and J. D. Landsberg. 1997. Shortand long-term effects of prescribed underburning on nitrogen availability in ponderosa pine stands in central Oregon. Canadian Journal of Forest Research 27:369-378.

Moore, M. M., W. W. Covington, and P. Z. Fulé. 1999. Reference conditions and ecological restoration: a southwestern ponderosa pine perspective. Ecological Applications 9:1266-1277.

Mulvaney, R. S. 1996. Nitrogen - inorganic forms. Pages 11231184 in D. L. Sparks, editor. Methods of soil analysis. Part 3: Chemical methods. SSSA Book Series 5. Soil Science Society of America, Madison, Wisconsin, USA.

Neary, D. G., C. C. Klopatek, L. F. DeBano, and P. F. Ffolliott. 1999. Fire effects on belowground sustainability: a review and synthesis. Forest Ecology and Management 122: $51-71$.

Newland, J., and T. H. DeLuca. 2000. Influence of fire on native nitrogen fixing plants and the soil $\mathrm{N}$ status of ponderosa pine forests in western Montana. Canadian Journal of Forest Research 30:274-282.

Northup, R. R., Z. Yu, R. A. Dahlgren, and K. A. Vogt. 1995. Polyphenol control of nitrogen release from pine litter. Nature 377:227-229.

Paavolainen, L., V. Kitunen, and A. Smolander. 1998. Inhibition of nitrification in forest soil by monoterpenes. Plant and Soil 205:147-154.

Persson, J., P. Högberg, A. Ekblad, M. Högberg, A. Nordgren, and T. Näsholm. 2003. Nitrogen acquisition from inorganic and organic sources by boreal plants in the field. Oecologia 137:252-257.

Pietikäinen, J., O. Kiikkilä, and H. Fritze. 2000. Charcoal as a habitat for microbes and its effect on the microbial community of the underlying humus. Oikos 89:231-242.

Prieto-Fernandez, A., M. Carballas, and T. Carballas. 2004. Inorganic and organic $\mathrm{N}$ pools in soils burned or heated: immediate alterations and evolution after forest wildfires. Geoderma 121:291-306.

Schimel, J. P., and J. Bennett. 2004. Nitrogen mineralization: challenges of a changing paradigm. Ecology 85:591-602.

Schimel, J. P., K. Van Cleve, R. G. Cates, T. P. Clausen, and P. B. Reichardt. 1996. Effects of balsam poplar (Populus balsamifera) tannins and low molecular weight phenolics on microbial activity in taiga floodplain soil: implications for changes in $\mathrm{N}$ cycling during succession. Canadian Journal of Botany 74:84-90.

Schoennagel, T., T. T. Veblen, and W. H. Romme. 2004. The interaction of fire, fuels, and climate across Rocky Mountain forests. BioScience 54:661-676.

Smithwick, E. A. H., M. Turner, M. C. Mack, and F. S. Chapin, III. 2005. Post fire soil N cycling in northern conifer forests affected by severe, stand replacing wildfires. Ecosystems 8:163-181.

SPSS. 2000. SPSS for Windows version 10. SPSS, Chicago, Illinois, USA.

Stark, J. M., and S. C. Hart. 1997. High rates of nitrification and nitrate turnover in undisturbed coniferous forests. Nature 385:61-64.

Stone, J. E., T. E. Kolb, and W. W. Covington. 1999. Effects of restoration thinning on presettlement Pinus ponderosa in northern Arizona. Restoration Ecology 7:172-182.

Suarez, D. L. 1996. Beryllium, magnesium, calcium, strontium, and barium. Pages 575-602 in D. L. Sparks, editor. Methods of soil analysis. Part 3: Chemical methods. SSSA Book Series 5. Soil Science Society of America, Madison, Wisconsin, USA.

Swetnam, T. W., and C. H. Baisan. 1996. Historical fire regime patterns in the southwestern United States since AD 1700. Pages 11-32 in C. D. Allen, technical editor. Fire Effects in Southwestern Forests: Proceedings of the Second La Mesa Fire Symposium, Los Alamos, New Mexico, March 29-31 1994. USDA Forest Service Rocky Mountain Forest and Range Experiment Station General Technical Report RMGTR-286, Fort Collins, Colorado, USA.

Veblen, T. T., and D. C. Lorenz. 1986. Anthropogenic disturbance and recovery patterns in montane forests, Colorado Front Range. Physical Geography 7:1-24.

Wagle, R. F., and J. H. Kitchen. 1972. Influence of fire on soil nutrients in a ponderosa pine type. Ecology 53:118-125.

Ward, B. B., K. J. Courtney, and J. H. Langenheim. 1997. Inhibition of Nitrosomonas europaea by monoterpenes from coastal redwood (Sequoia sempervirens) in whole-cell studies. Journal of Chemical Ecology 23:2583-2598.

Wardle, D. A., L. R. Walker, and R. D. Bardgett. 2004. Ecosystem properties and forest decline in contrasting longterm chronosequences. Science 305:509-513.

White, C. S. 1991. The role of monoterpenes in soil nitrogen cycling processes in ponderosa pine. Biogeochemistry 12:43-68.

Wright, R. J., and S. C. Hart. 1997. Nitrogen and phosphorus status in a ponderosa pine forest after 20 years of interval burning. Ecoscience 4:526-533.

Zackrisson, O., M. C. Nilsson, and D. A. Wardle. 1996. Key ecological function of charcoal from wildfire in the Boreal forest. Oikos 77:10-19. 